\title{
Ethnobotanical Study Of Fig Tree (Ficus Carica L.) And Olive (Olea Europaea L.) From Tetouan Province In Morocco And Study Their Antimicrobial Activity
}

\author{
Zakaria MENNANE ${ }^{*}$., Zahira TABET ${ }^{1}$., Btissam El kharraz ${ }^{1}$, ,Touria Aabid ${ }^{1}$.,TOUIL Souhaila ${ }^{1}$.,Adnan Emrani ${ }^{1}$., Jamal \\ Abrini $^{1}$ and Noureddine ELMTILI ${ }^{1}$ \\ $1^{\circ}$ Equipe alimentation et santé ; Laboratoire de biologie et santé, Faculté de Sciences Tétouan ; Université Abdelmalek Essaidi
}

\begin{abstract}
This study we have conducted an ethnobotanical survey and antimicrobial activity in Tetouan province to identify the use of the famous plant species in traditional medicine : fig tree and Olive and follow-up of antimicrobial activity during three stages for green, pink and black olives and mixing activity of olive and fig extracts. 80 questionnaire sheets were done during April-June 2019, and the method of diffusion was used for the antimicrobial activity.Bacteria and yeasts were used: Staphylococcus aureus, Pseudomonas aeruginosa, and Klebsiella pneumoniae, E.coli and Candida albicans. The results revealed that $32 \%$ of farmers use olive oil for the initial treatment of respiratory diseases, and $22 \%$ use it for digestive system problems and $13 \%$ use it as a treatment of the nervous system.However, fig tree is used against insect bites, as an inhibitor of the growth of certain cancerous tumors, diabetes and certain viral infections. The ethanol extracts showed good inhibitory effects against most strains of bacteria and yeast. Also for the majority of strains tested, it was found that in December (black olive), activity is stronger, and that the mixture of ethanol extracts with ethanol extracts of fig tree it strengthened them.
\end{abstract}

Key words: Fig; Antimicrobial; ethnobotanical; olive; traditional medicine

\section{INTRODUCTION}

Fig tree is considered as a medicinal plant that is very old in Morocco, however in some areas (Taounate, Chaouen, Ouezzane) dried fig (Chriha) was exchanged with cereals [1].

Its domestic production in 2014 was estimated 126554 tonnes [2)].

Studies have reported the use of traditional medicinal fig trees in different regions of Morocco (3);(4); (5).

In research on infectious microbes, it was shown that the ethanol and aqueous extract of fig leaves prevented the proliferation of all the bacteria and yeasts studied that cause certain urinary tract and skin infections and food poisoning (6).

Hassan Gilani also emphasised the importance of fig leaf extracts in protecting the intestines of rabbits, supporting their movement and preventing (7)

Olive oil is rich with polyphenols that have antioxidant properties (8) to reduce free radicals (9), especially the action of oleuropein (10).

The content of phenolic compounds in olive leaves reaches up to $250 \mathrm{mg} / \mathrm{g} \mathrm{MS}$ (11). As well as these products are characterized by their antimicrobial activity (12).

In a synthesis paper (13), some of the research studies on figs and olives were found to be effective when combined.

it was found in a study (14) that figs and olives are a source of polyphenoids, which increases their antioxidant activity and promotes the formation of proteasomes, leading to protection against cancer fig and olive extract tripled the shelf life of milk (15) and it was found that consumption of olives and figs in a ratio of 1:7, as indicated in the Holy Qur'an, contributed to the body's production of Metallothionein, which stops production at 60 years of age and plays an active role in the elimination of heavy metals from the body (16) and protects against Alzheimer's disease (17)

The objective of this work is to study the traditional use of fig and olive trees in the region of Tangier-Tetouan by questionnaire sheets, and study the antimicrobial activity of these plants.

\footnotetext{
* Corresponding author: menzakaria@,hotmail.com
} 


\section{MATERIALS AND METHODS}

\subsection{Ethnobotanical study}

\subsubsection{Questionnaire of study}

Study of fig and olive trees was carried out in the Tangier-Tetouan-El Hoceima region. The different points of investigation according to the administrative redistricting of the municipalities existing in the cities that were studied.

Once in the field, questionnaire was done. We have completed 80 questionnaire sheets during April-June 2019. The time spent on each interview varies from 15 to 30 minutes, during each interview, all information about the survey was collected, as well as the traditional use of fig and olive trees.

Each questionnaire sheet has two components:

The first related to age, sex, education (illiterate, primary, at most), the origin of the information, the season and the source (Local or imported).

The second related to the parts used in the plant, the type of disease treated by each part of the plant and the method of preparation.

\subsubsection{Distribution of study sites}

Survey sets were conducted in the following communities( Figure1):

Beni Hassan and Khmis Anjra province of Tetouan, Beni Ahmed and Talambout province of Chefchaouen, Malousa and Aine dalya province of Tangier and province of Taounat

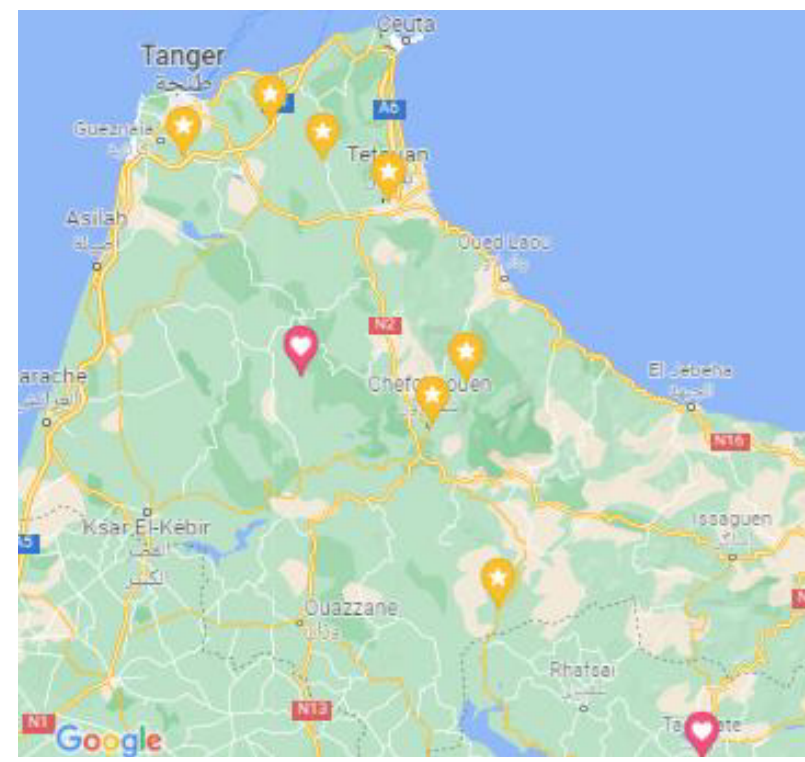

Fig. 1 Breakdown of survey points in the TangierTetouan-El Hoceima region

\subsubsection{Type of informants}

The value of an ethnobotanical survey depends on the source of information. For example, information from professional informants is the most reliable.

Information on endemic medicinal plants of the sites visited can also be collected.

\subsubsection{Data analysis}

The data collected on survey data sheets has been transferred to a database and analyzed by Excel 2010 software that allows a set of useful operations to be performed.

\subsection{Preparation of extract}

\subsubsection{Plants collection}

Olive and fig leaves were collected in OctoberDecember 2019 from province Tetouan. The leaves were dried at mesophyll temperature for 15 days, after it were turn into powder and stored correctly until extraction

\subsubsection{Aqueous extract}

Using the Soxhlet method, $100 \mathrm{~g}$ of powder from olive or fig leaves were extracted for 24 hours in $500 \mathrm{ml}$ of distilled water. Then, a rotary evaporator is used to dehydrate the water[18].

\subsubsection{Organic extracts}

$100 \mathrm{~g}$ of powder from olive or fig leaves were extracted by the Soxhlet method for 24 hours in $500 \mathrm{ml}$ of ethanol. Then, a rotary evaporator is used to remove the ethanol [19].

\subsection{Study of antimicrobial activity}

\subsubsection{The strains tested}

Bacteria and yeasts that were isolated from different disease infections were used: Staphylococcus aureus (SA) ATCC, Pseudomonas aeruginosa(PA), Klebsiella pneumoniae (KP), E.coli (EC) and Candida albicans (CA).

\subsubsection{Method of diffusion}

Antibacterial activity was carried out using MuellerHinton's (MH) method of diffusion. The MH medium is evenly seeded using a sterile swab by a saline suspension $(\mathrm{NaCl} 0.9 \%)$, previously adjusted using the $0.5 \mathrm{Mac}$ Farland standard to a turbidity of about 106 bacteria $/ \mathrm{ml}$. 
After 24 hours of incubation at $37 \mathrm{oC}$ for bacteria and at $30 \mathrm{oC} / 48 \mathrm{~h}$ for yeast, the diameter of the inhibition zones was measured. The manipulations were repeated 3 times.

\subsubsection{A follow-up of antimicrobial activity}

A follow-up of antimicrobial activity in three stages: premature stage « green olives», para-ripened stage « pink olives » and ripening stage ( black olives) and the activity of mixing extracts of olives and figs

\section{RESULTS AND DISCUSSION}

\subsection{Ethnobotanical study}

Ethnobotany is considered a study to knowledge local populations and their relationship with plants. The results obtained from this ethnobotanical survey on the traditional using of fig and olive trees in medicine in the Tangier-Tetouan-El Hoceima region are indicated.

Survey results: olive and fig trees showed that men represent $58 \%$ and $60 \%$ respectively comparing with women $42 \%$ and $40 \%$ respectively due to men often work in the fields. For age the category 40 and over was dominated with a rate of $64 \%$ and $67 \%$ respectively due to the last reason too (Table 1).

Table 1. Results of the first part of the olive tree survey

\begin{tabular}{|l|l|c|}
\hline Sex & Male & $58 \%$ \\
\cline { 2 - 3 } & female & $42 \%$ \\
\hline \multirow{2}{*}{ Age } & $<40$ & $64 \%$ \\
\cline { 2 - 3 } & $>40$ & $36 \%$ \\
\hline \multirow{2}{*}{$\begin{array}{l}\text { Level } \\
\text { School }\end{array}$} & $\begin{array}{l}\text { College } \\
\text { and plus }\end{array}$ & $56 \%$ \\
\hline \multirow{2}{*}{$\begin{array}{l}\text { Derived } \\
\text { from } \\
\text { olives } \\
\text { consum } \\
\text { ed }\end{array}$} & Olive + olive oil & $34 \%$ \\
\cline { 2 - 3 } & Oive & $12 \%$ \\
\hline \multirow{2}{*}{$\begin{array}{l}\text { extracti } \\
\text { on }\end{array}$} & olive oil & $64 \%$ \\
mode & Modern system & $58 \%$ \\
\cline { 2 - 3 } & traditional system & $42 \%$ \\
\hline
\end{tabular}

People who have primary education were the most investigated in this study with $56 \%$ and $67 \%$ respectively Only $30 \%$ of farmers grow olive trees because it takes some years before starting production, $88 \%$ of people prepared olives in their homes in different ways, and $62 \%$ use machines for the extraction therefore, the traditional system does not exceed $38 \%$, due to the benefits of technology system such as the performance and processing capacity.

$52 \%$ do not use olive snack, $28 \%$ sell it to traditional ovens and $20 \%$ use it for livestock feed.

Most farmers use olive oil for initial treatment in many diseases. $50 \%$ of which $32 \%$ use it for respiratory diseases, lubricating the chest and neck in case of cough. And those who use it for digestive system account for $22 \%$, able to soften the stomach and get rid of constipation. People who use it as a treatment of nervous system, reaching $13 \%$, as well as $33 \%$ use it as a treatment of certain abnormalities of organ function such as insertion of a small amount of olive oil in the ear in case pain, or when an insect is penetrating(Table 2 ).

Table 2. Results of the second part of the olive tree survey

\begin{tabular}{|c|c|c|}
\hline \multirow{4}{*}{$\begin{array}{l}\text { Medical } \\
\text { use }\end{array}$} & Respiratory device & $32 \%$ \\
\hline & Digestive device & $22 \%$ \\
\hline & Nervous system & $13 \%$ \\
\hline & Other bodies & $33 \%$ \\
\hline \multirow{3}{*}{$\begin{array}{l}\text { Using } \\
\text { of } \\
\text { the } \\
\text { leaves }\end{array}$} & Yes & $42 \%$ \\
\hline & Non & $28 \%$ \\
\hline & Sometimes & $30 \%$ \\
\hline \multirow{2}{*}{$\begin{array}{l}\text { Mastery } \\
\text { of } \\
\text { preparat } \\
\text { ion }\end{array}$} & Yes & $88 \%$ \\
\hline & Non & $12 \%$ \\
\hline \multirow{3}{*}{$\begin{array}{l}\text { Using } \\
\text { of the } \\
\text { olive } \\
\text { residue }\end{array}$} & Yes & $20 \%$ \\
\hline & Non & $52 \%$ \\
\hline & sometimes & $28 \%$ \\
\hline
\end{tabular}

The survey showed that $42 \%$ of farmers use olive leaves to treat certain diseases, such as diabetes when cooking olive leaves in water and drinking the product after filtering. In addition $30 \%$ use it for livestock feed.

oleuropein was extracted from the leaves o. europaea has pharmacological properties including spasmolytic, immunostimulant, cardioprotective, hypotensive, antihyperglycemic, antimicrobial and anti-inflammatory effects (21), (22), (23).

It also used for lowers blood pressure in animals and increases blood flow in the coronary arteries (A. 24)

Phenolic compounds in olive fruits, especially hydroxytyrosol and oleuropein have antibacterial properties (25)

The origin of the information for the majority of fig tree respondents $(67 \%)$ is its achievements in traditional medicine. Also, using fig as a treatment was reported nationally;(20); (5). as antidiabetic, anti-fever, against colic, and warts (Table 3 ) 
Worldwide, traditional medicine uses of Ficus carica have been described for more than 40 types of diseases. And different metabolites were isolated, and its extracts showed pharmacological activities (26). Also is Useful for the treatment of various disorders such as ulcers in the oral cavity, vomiting, burns, gynecological problems (27)

In experimental work on rats Constipation decreased after fig use, and that the number of feces, water content, and condition distal of colon has been improved. The study recommends treating chronic constipation with figs (28). Also The use of fig leaves as a feed presented to experimental rats can help correct hyperglycemia due to diabetes.the antioxidant power and fibers of figs and its leaves are responsible for this activity.(29)

in another experiment, the use of fig latex to treat warts gives good results in a short time, and without side effects, Also a simplicity of use, and a low rate of recurrence. Proteolytic activity of latex enzymes can probably be the active principle(30).

Table 3. Results of the fig tree survey

\begin{tabular}{|l|l|c|}
\hline \multirow{2}{*}{ Sex } & Male & $60 \%$ \\
\cline { 2 - 3 } & female & $40 \%$ \\
\hline Age & $<40$ & $33 \%$ \\
\cline { 2 - 3 } & $>40$ & $67 \%$ \\
\hline \multirow{2}{*}{$\begin{array}{l}\text { Level } \\
\text { School }\end{array}$} & $\begin{array}{l}\text { Primary } \\
\text { College }\end{array}$ \\
\hline \multirow{2}{*}{$\begin{array}{l}\text { Family } \\
\text { Situation }\end{array}$} & Married & $67 \%$ \\
\cline { 2 - 3 } & Single & $33 \%$ \\
\hline \multirow{2}{*}{$\begin{array}{l}\text { Origin of } \\
\text { informati } \\
\text { on }\end{array}$} & $\begin{array}{l}\text { Traditional } \\
\text { medicine }\end{array}$ & $33 \%$ \\
\cline { 2 - 3 } & $\begin{array}{l}\text { Other people's } \\
\text { experience }\end{array}$ & $33 \%$ \\
\cline { 2 - 3 } & Reading & $10 \%$ \\
\hline
\end{tabular}

\subsection{Study of antimicrobial activity}

The results of antibacterial activity of the aqueous and ethanolic extracts of $\mathrm{O}$. europaea leaves and Ficus carica leaves are presented in Table 4. The ethanolic and aqueous extracts of olive leaves from Tetouan region was the most active; it was active against all bacteria tested by maximum inhibitory zone against $\mathrm{P}$. aeruginosa $(25 \mathrm{~mm})$ and $(23 \mathrm{~mm})$ respectively while It was also active against sa (1 and 3 ) and $\mathrm{P}$. aeruginosa (1) (16 minimum inhibitory zone was against E. coli (8) (11 $\mathrm{mm}) . \mathrm{mm}$ and $14 \mathrm{~mm}$ respectively).
Table 4 : Screening antibacterial activity of olive (Olea europaea L.) leaves and Ficus carica leaves extracts collected from Tetouan region of Morocco.

\begin{tabular}{|c|c|c|c|c|c|c|}
\hline \multirow{2}{*}{$\begin{array}{l}\text { The } \\
\text { extracts }\end{array}$} & & \multicolumn{5}{|c|}{ Diameter in $\mathrm{mm}$} \\
\hline & Month & $S A$ & $P A$ & $K P$ & $E C$ & $C A$ \\
\hline \multirow{3}{*}{$\begin{array}{l}\text { Ethanol } \\
\text { extracts of } \\
\text { olive } \\
\text { (EEO) }\end{array}$} & october & 23 & 12 & 17 & 19 & 17 \\
\hline & $\begin{array}{c}\text { novemb } \\
\text { er }\end{array}$ & 19 & 12 & 18 & 13 & 24 \\
\hline & $\begin{array}{c}\text { decemb } \\
\text { er }\end{array}$ & 12 & 13 & 18 & 13 & 24 \\
\hline $\begin{array}{c}\text { ethanol } \\
\text { extracts of } \\
\text { fig } \\
\text { (EEF) }\end{array}$ & & 23 & 12 & 17 & 19 & 17 \\
\hline $\begin{array}{l}\text { Mixture } \\
\text { (EEO+EE } \\
\text { F) }\end{array}$ & & 10 & 16 & 18 & 18 & - \\
\hline \multirow{3}{*}{$\begin{array}{l}\text { Aqueous } \\
\text { Extracts } \\
\text { of leaves } \\
\text { of olive } \\
\text { (AEO) }\end{array}$} & october & 20 & 17 & 20 & - & - \\
\hline & $\begin{array}{c}\text { novemb } \\
\text { er }\end{array}$ & 15 & - & 18 & 10 & 13 \\
\hline & $\begin{array}{c}\text { decemb } \\
\text { er }\end{array}$ & 12 & 15 & 22 & 16 & 15 \\
\hline $\begin{array}{l}\text { Aqueous } \\
\text { Extracts } \\
\text { of leaves } \\
\text { of Ficus } \\
\text { carica } \\
\text { (AEF) }\end{array}$ & & 0 & 0 & 0 & 0 & 0 \\
\hline $\begin{array}{c}\text { Mixture } \\
(\mathrm{AEO}+\mathrm{AE} \\
\mathrm{F})\end{array}$ & & 12 & 14 & 23 & 16 & - \\
\hline
\end{tabular}

Legend: Staphylococcus aureus (SA), Pseudomonas aeruginosa(PA), Klebsiella pneumoniae (KP), E.coli (EC) and Candida albicans (CA).

The results of antimicrobial activity indicated that ethanol extracts showed good inhibitory effects against most strains of bacteria and yeast. Also for the majority of strains tested, it was found that in December (black olive), activity is stronger, and that the mixture of ethanol extracts of olive with ethanol extracts of fig tree and the mixture of Aqueous Extracts of leaves of Ficus carica (average 0mm)with Aqueous Extracts of leaves of olive (average 16mm)it strengthened them (average $16.5 \mathrm{~mm})$.

Also, Lamhamdi (14) has shown that the use of the two fruits, fig and olive, increases their antioxidant activity. And that the addition of the aqueous extract of these two plants according to El Dessouky (15) triples the shelf life of the seeded milk

\section{Conclusion}

The ethnobotanical study of fig and olive trees, in the various sites of the Tangier-Tetouan-ElHoceima region of Morocco, has collected information on the different 
uses in traditional medicine of these two plants, the fig tree has been used against asthma, colds, coughs, constipation and warts. So for the olive tree, most farmers use olive oil to treat respiratory diseases, digestive system, nervous system and get rid of constipation, ear infections and others.

Also for the majority of strains tested, it was found that in December (black olive), activity is stronger, and that the mixture of extracts of olive with extracts of fig tree strengthened them $16.5 \mathrm{~mm}$ ).

\section{References}

1- A.Oukabli, Bulletin mensuel d'information et de liaison du pntta. 106 (2003).

2-FAOSTA(2014), http://www.fao.org/faostat/en/\#data/TP.

3- J.Bellakhdar, contribution à l'étude de la pharmacopée traditionnelle au maroc : La situation actuelle, les produits Les sources du savoir( Ibis Press. 263 (1997))

4- M.Eddouks , M..Maghrani, , A .Lemhadri,., L .Ouahidi,.., H .Jouad,., J. Ethnopharmacol. 82, 23(2002).

5- A..Tahraoui, J. El-Hilaly,. Z.H..Israili, , B .Lyoussi,., J. Ethnopharmacol. 110 (2007).

6-G.Askari, A.Kahouadji, K.Khedid, L.Ouaffak, M.Mousaddak, R.Charof and Z.Mennane, J. Mater. Environ. Sci 4, 1 (2013)

7- A.H. Gilani, M.H. Mehmood, K.H. Janbaz, A. Khan and S.A. Saeed, J. Ethnopharmacol. 119, 1 (2008).

8-D. Ollivier, E.Boubault, C. Pinatel, S.Souillol,M. Guérère, J.Artaud.. Annales des falsifications, de l'expertise chimique et toxicologique,(2ème Semestre. $\mathrm{N}^{\circ}$ 965(2004))

9- HK .Hamdi, R .Castellon. Biochem Biophys Res Commun 334,3 (2005).

10- M .Alirezaei,., O .Dezfoulian,., A .Kheradmand,., Sh. Neamati; Khonsari, A..Pirzadeh Iran J Vet Res, 13, 3 (2012).

11-S. Mylonaki \& E. Kiassos \& D. P. Makris \&P.Kefalas. Anal Bioanal Chem 392, 977 (2008)

12- H. S. Lahdibi, H .El Berny, M .El Karkour, A.Qasmaoui, R .Charof, Z. Mennane. Der Pharma Chem 9,13 2017,

13- Z.MENNANE., S. Mighiss; J.Abrini; N.ELMTILI. International Eajaz academic publishing 6, 1 (2021)

14- A .Lahmadi, H. Filali , H .Samaki, A. Zaid, S. Aboudkhil,. Bioinformation 15,3 (2019)

15-M.El Dessouky A.,M.Samir D,Azza H. Mohamed , Y A. El-Khateeb , S. E. Hamed, Foods 9,5 (2020).

16- T.I. Khalifa, A Scientific Miracle

http://navedz.wordpress.com/tag/japanese/; Accessed

(2009).
17-E. S.G. Shaltout.Thesis ,Faculty of medicine-assiut university 2012

18- J J.B. Harbone, Photochemical methods a guide to modern techniques of plant analysis (Halsted press, ,New York, 1976)

19- A.M. Dub, A.M. Dugani, Libyan J. Med. 8 (2013).

20- O.Benkhnigue, , L.Zidane, , M.Fadli, , H.Elyacoubi, , A.Rochdi, , A.Douira, , Acta Bot. Barcinon 53 ,191-216 (2010)

21-. H.F.Al-Azzawie, M.S.S. Alhamdani, Life Sci. 78, 1371-1377 (2006)

22- A.N.Sudjana .. C.D. Orazio, V. Ryan, N. Rasool, J. $\mathrm{Ng}$, N. Islam, T.V. Riley, K.A Hammer; Antimicrob. Agents 33,5( 2009)

23- O.B.Garcia., J. Castillo, J. Lorente, A. Ortuno, J.A. Del Rio, Food Chem 68, 457-462 (2000)

24- A..Zarzuelo., J. Duarte, J. Jimenez, M. Gonzales, Planta Med 57, 417-419 (1991),

25- M.G.Soni ., G.A. Burdock, M.S. Christian, C.M. Bitler, R. Crea, Food Chem. Toxicol 44, 7 (2006)

26- B.S.Badgujar, V.V.Patel,.A.H. Bandivdekar, R. T.. Mahajan,A review, Pharm Biol 11, 1487-1503 (2014)

27- PV. Prasad, PK .Subhaktha, A. Narayana, Rao MM. , Bull Indian Inst Hist Med (Hyderabad). 36, 1 (2006)

28-H.Y. Lee, J.Kim, H.Jeung, Cha-Uk Lee, D.Kim, B. Li, G Lee, M.Sung, K.Ha, H. Back, S.Kim, S.Park, M Oh, M.Kim, J.Jeon, Y.Im, M.Hwang, Byung-Ok So, S.Shin, W.Yoo, H. Kim, Han-Jung Chae, SooWan Chae, Food Chem. Toxico 3-4, 895-902(, 2012

29- FA. El-Shobaki, AM. El-Bahay, RSA. A. ElMegeid, N. Esmail,. World J Dairy Food Sci 5,1 (2010)

30- Bohlooli S, Mohebipoor A, Mohammadi S, Bohlooli S, Mohebipoor A, Mohammadi S, M Kouhnavard, S Pashapoor.. Int J Dermatol 46:524-6 (2010) 